\title{
Nova pipeta para inseminação intra-uterina em suínos*
}

\author{
GUSTAVO NOGUEIRA DIEHL \\ Fernando Pandolfo Bortolozzo (Orientador - UFRGS) \\ Ivo Wentz (Co-Orientador - UFRGS)
}

Banca: David Emilio Santos Neves de Barcellos (UFRGS), Fabiane Ferreira Mendonça (UNICRUZ), Guilherme Borchardt Neto (UNICRUZ)

\begin{abstract}
A inseminação intra-uterina (IAU) permite reduzir o número de espermatozóides e o volume de diluente em comparação à inseminação tradicional. No entanto, a técnica ainda apresenta algumas limitações a serem superadas para que seja uma alternativa de diminuição dos custos de cobertura. O objetivo deste trabalho foi avaliar o desempenho reprodutivo de 423 fêmeas suínas de ordem de parto 1 a 9 submetidas à inseminação intra-uterina (IAU), com um novo modelo de pipeta (T1) cuja extremidade não é fixada na cérvix ou uma pipeta de IAU modelo Verona ${ }^{\circledR}$ e que permite a fixação da sua extremidade em espiral na cérvix (T2). Para comparar as duas pipetas foi considerado o grau de dificuldade para realização das inseminações, o tempo necessário para realizá-las, presença de sangramento após a inseminação, a presença de refluxo no momento da inseminação, as taxas de retorno ao estro (TR), de prenhez (TPR) e de parto ajustada (TPA), além do número de leitões nascidos (NT). As fêmeas de ambos os grupos foram inseminadas com doses de 1 bilhão de espermatozóides, em intervalos de 24 horas. A passagem do cateter de IAU através da cérvix foi possível em 95,9\% das fêmeas, sem diferença entre os tratamentos ( $\mathrm{P}>0,05)$. Em pelo menos uma das inseminações, foi observado sangue no cateter, após a realização da IAU, em 20,6\% das fêmeas do T1 e 15,2\% das fêmeas do T2 (P=0,14). O tempo médio necessário para realizar a inseminação foi de 2,1 minutos para o T1 e 2,3 minutos para o T2 $(\mathrm{P}=0,26)$. O percentual de fêmeas com refluxo de sêmen no momento da inseminação foi maior ( $\mathrm{P}=0,01)$ no $\mathrm{T} 1(8,4 \%)$ em comparação ao T2 (2,9\%). Não houve diferença (P>0,05) nas variáveis TR (8,0 e 4,8\%), TPR $(93,4$ e 96,2\%) e NT (12,4 e 12,7 leitões) entre T1 e T2, respectivamente. A TPA do T1 (90,6\%) apresentou tendência ( $\mathrm{P}=0,07)$ de ser inferior à do T2 (95,1\%). No T1, as fêmeas primíparas apresentaram maior TR e menor TPA em comparação às pluríparas ( $\mathrm{P}<0,05)$. Os resultados mostram que a nova pipeta pode ser utilizada sem prejuízos ao desempenho reprodutivo, em fêmeas pluríparas, mas sugerem cautela para sua utilização em fêmeas primíparas.
\end{abstract}

Descritores: inseminação intra-uterina, pipeta, fêmeas primíparas, suínos.

Apresentada: 18 março 2005

"Dissertação de Mestrado n.405 (Especialidade: Fisiopatologia da Reprodução). 57f. Programa de Pós-graduação em Ciências Veterinárias [www.ufrgs.br/ ppgcv], Faculdade de Veterinária - UFRGS, Porto Alegre/RS. CORRESPONDÊNCIA: G. N. Diehl [gustavond@yahoo.com.br] \& F. P. Bortolozzo [fpbortol@ufrgs.br]. 


\title{
New pipette for intrauterine insemination in pigs ${ }^{* *}$
}

\author{
GUSTAVO NOGUEIRA DIEHL \\ Fernando Pandolfo Bortolozzo (Adviser - UFRGS) \\ Ivo Wentz (Co-Adviser - UFRGS)
}

Committee: David Emilio Santos Neves de Barcellos (UFRGS), Fabiane Ferreira Mendonça (UNICRUZ), Guilherme Borchardt Neto (UNICRUZ)

Intrauterine insemination (IAU) allows the reduction of the number of spermatozoa and the volume of extender if compared with the traditional artificial insemination. However, to be an alternative for reducing the insemination costs, this technique still presents some limitations that need to be overcame. The aim of this work was to evaluate the reproductive performance of 423 swine females of parities 1 to 9 inseminated with two different intrauterine artificial insemination (IAU) pipettes. The first group (T1) was formed by sows inseminated with a new pipette whose extremity was not fixed in the cervix. The second group (T2) was formed by females inseminated with a Verona ${ }^{\circledR}$ pipette model, with its extremity fixed in the cervix. For the comparison of these pipettes were considered the degree of difficulty to perform the insemination, the time spent during the insemination, the presence of blood after insemination and of semen backflow during insemination. Return to oestrus rate (RO), pregnancy rate (PR), adjusted farrowing rate (AFR) and total litter size (TLS) were also evaluated. All females were inseminated with 1 billion spermatozoa per dose applied at intervals of 24 hours. The catheter of IAU was successfully inserted in $95.9 \%$ of females without difference between treatments $(\mathrm{P}>0.05)$. The presence of blood, in at least one insemination, was observed in $20.6 \%$ of T1 and $15.2 \%$ of T2 females $(\mathrm{P}=0.14)$. The average time to perform the insemination was 2.1 for $\mathrm{T} 1$ and 2.3 minutes for $\mathrm{T} 2$ females $(\mathrm{P}=0.26)$. The percentage of females with semen backflow was significantly higher $(\mathrm{P}=0.01)$ in $\mathrm{T} 1(8.4 \%)$ compared to $\mathrm{T} 2(2.9 \%)$ group. There were no differences $(\mathrm{P}>0.05)$ in RO (8.0\% and 4.8\%), PR (93.4\% and 96.2\%) and TLS (12.4 and 12.7 piglets) between T1 and T2 groups, respectively. AFR of T1 (90.6\%) tended $(\mathrm{P}=0.07)$ to be lower than that of T2 (95.1\%). Primiparous females of T1 showed higher $\mathrm{RO}$ and lower AFR in comparison to pluriparous $(\mathrm{P}<0.05)$. The results show that the new pipette can be used in pluriparous females without compromising their reproductive performance. However, caution is necessary for the utilization of this new pipette in primiparous females.

Key words: intrauterine insemination, pipette, primiparous females, swine.

Presented: 18 March 2005

\footnotetext{
**Master’s Thesis \#405 (Field: Theriogenology). 57p. Graduate Program in Veterinary Sciences [www.ufrgs.br/ppgcv], Faculdade de Veterinária, Universidade Federal do Rio Grande do Sul (UFRGS), Porto Alegre/Brazil. CORRESPONDENCE: G.N. Diehl [gustavond@ yahoo.com.br] \& F.P. Bortolozzo [fpbortol@ufrgs.br].
} 